\title{
THE NORTHERN IRELAND TROUBLES: WHAT WAS THERE TO PHOTOGRAPH?
}

\begin{abstract}
Peace Agreement that brought with it a promise of 'lasting peace' in Northern Ireland. However, the past has continued to haunt large sections of the population whose lives have been scarred by the violence they experienced. The article examines how contemporary photographers have attempted to come to terms with the effects of political violence over the years. It does so in relation to how they approach the question of 'showing' that violence. Some, like Paul Seawright or David Farrell, for example, prefer an allusive, lateral approach that focuses on the sometimes invisible traces of violence. In contrast, the Belfast-based photographer, Malcolm Craig Gilbert takes a more frontal approach that insists on presenting the viewer with images of trauma, sometimes at the risk of appearing over-explicit. Whatever strategy is adopted - hiding or revealing - the onlooker requires a grounding in the visual codes that Northern Ireland society has developed to communicate with itself. The article will look at some of the work that emerged before and during the Peace Process so as to assess its contribution to a broader understanding of the ways the traces of political violence continue to impact on society in Northern Ireland.
\end{abstract}

Keywords: Northern Ireland, Troubles, photography, political violence, trauma

2018 sees the $20^{\text {th }}$ anniversary of the signing of a peace agreement that brought with it a promise of 'lasting peace' in Northern Ireland by supposedly ending violence on the streets through a policy which involved the progressive disarming and disbandment of the various republican and loyalist paramilitary organisations. This 'decommissioning' was tied in to a 'de-militarisation' of the region through the scaling down of security force activity and the return of the police force to an exclusively civilian role. However, the effects of paramilitary influence continue to be felt within Northern Irish society. Furthermore, the legacies of trauma caused by the violence generated during the period of the Troubles have proved difficult to resolve.

As was clear from the major exhibition, The Art of the Troubles, ${ }^{1}$ shown at the Ulster Museum in Belfast in 2014, or Liam Kelly's landmark text, Thinking Long:

1 The exhibition ran at the Ulster Museum from $11^{\text {th }}$ April to $7^{\text {th }}$ September 2014. In February 2015 the Arts Council of Northern Ireland launched an on-line Troubles Archive-see: http://www.artscouncil-ni.org/news/launch-of-first-digital-archive-of-troubles-art-which has been incorporated into 
Contemporary Art in the North of Ireland published in $1996,{ }^{2}$ the visual arts have constantly sought to engage with the impact of political violence in Northern Ireland.

Photographers have taken different approaches to the issue of 'showing' the violence connected with the Troubles. In their overviews of photography in Ireland and in Northern Ireland, Justin Carville ${ }^{3}$ and Colin Graham ${ }^{4}$ discuss how photojournalists working for the international media very quickly imposed what was to become a broadly accepted representation of the violence that took hold of Northern Ireland at the end of the 1960s. Coverage of the 'civil unrest' obeyed the conventions imported from other conflict zones by photographers for whom Northern Ireland was only one stop en route for what Carville calls "the latest newsworthy war". ${ }^{5}$ This reading of the violence, associated with photographers like Abbas ${ }^{6}$ or Clive Limpkin, ${ }^{7}$ produced a series of particularly powerful 'iconic' images at this time. ${ }^{8}$ However, the impact of this body of work was such that — so it has been argued — much of the photography subsequently produced in Northern Ireland has been constructed in direct reaction to it. Thus, Graham cites a 1983 article in the Irish contemporary visual arts magazine, Circa, in which Belinda Loftus, author of the remarkable two-part study, Mirrors, ${ }^{9}$ criticised the image of the Troubles imposed by photojournalists and underlined how the fact of living in Northern Ireland and experiencing its trauma at first hand (what Graham calls "indigenousness") produced radically different visual responses to the violence, particularly in terms of an understanding of its multiple subtexts, an aspect which, she claimed, was perceptible in the work itself. ${ }^{10}$

\section{"There was nothing to photograph"}

As regards the photographers who fulfil Loftus's criteria of "lived experience" and "local knowledge" of life in Northern Ireland during the Troubles, it is striking that many of them who deal with the issue of political violence in their work have

ww.troublesarchive.com [access: 9.11.2018]. This archive contains artwork from the period as well as a timeline, artists' profiles and a number of themed essays such as D. Long, Visual Art and the Conflict in Northern Ireland, Belfast: Arts Council of Northern Ireland, n.d.

2 L. Kelly, Thinking Long: Contemporary Art in the North of Ireland, Kinsale: Gandon Editions, 1996.

3 J. Carville, Photography and Ireland, London: Reaction Books, 2011.

4 C. Graham, Northern Ireland: Thirty Years of Photography, Belfast: Belfast Exposed/MAC, 2013.

5 J. Carville, Photography and Ireland, p. 131.

6 See B. Lardinois, V. Williams (eds.), Magnum Ireland, London: Thames \& Hudson, 2005.

7 See the classic text, C. Limpkin, The Battle of the Bogside, Harmondsworth: Penguin Books, 1972.

8 The photograph of the young boy with the Molotov cocktail on the cover of the Limpkin book has taken on such iconic status.

9 B. Loftus, Mirrors: William III and Mother Ireland, Dundrum: Picture Press, 1990; B. Loftus, Mirrors: Orange and Green, Dundrum: Picture Press, 1994. In these texts, Loftus examines the history of the political iconography of the Northern Ireland conflict. Wherever possible, she traces the popular representations back to their roots in the fine arts.

10 Loftus is quoted in C. Graham, Northern Ireland..., pp. 25-31. 
chosen to avoid tackling it head-on, preferring to approach it obliquely and to operate in the area of absences.

An obvious example here is Paul Seawright's Sectarian Murder series (1988). ${ }^{11}$ The images in this series focus on the sites-playgrounds, tourist spots, carparks, bits of waste ground-where the bodies of victims of sectarian murders carried out in the 1970s were found. Invariably, the image is accompanied by a short text taken from a newspaper cutting, containing in uniformly neutral prose the basic information about the incident: the date of the murder, its location, the age of the victim, whether or not he or she had been tortured. Although the title used to refer to the series is Sectarian Murder, the texts pointedly never refer to the religious origin of the victim. ${ }^{12}$ The juxtaposition of the images and the texts underlines the contrast between the banality of the sites and the acts of extreme violence that had taken place there some fifteen years earlier. Although the text re-connects the space with its traumatic past, transforming the waste ground or the children's playground into a lieu de mémoire, the focus is on absences, on what is at once there and out of reach. An essential part of Seawright's strategy is the way he, as a photographer, invests the space of the crime and the space of the photograph. This involves a number of approaches, both spatial and textual. As Liam Kelly explains in Thinking Long, Seawright sometimes retraced the route of the victim's last journey from the place where he was kidnapped to the murder site. He also worked in the archive tracking down the traces the events had left in the local press. All of this preceded the technical work at the site of the murder-defining the frame, choosing the light, selecting the angle, often from the point of view of the victim. Such a painstaking, restrained and respectful effort at contextualisation, repeated for each murder scene-Seawright includes only one shot from each site in the series - could not be further from the visual strategy of the grand reporter eager to capture an image whose immediacy will (appear to) carry a message understandable by all. Seawright's strategy, by contrast, requires an investment in terms of time - on the part of the artist who will come at the subject from a number of angles - and a minimum of effort on the part of the viewer if they are to begin to connect to the image. In both cases, the 'focus' of the image is on the absence of traces of the event, on its effacement from the surroundings, on the fact that there is "nothing to photograph". Seawright's photographs, by their very existence, interrogate the empty spaces of the murder sites and in so doing give those events a second, alternative existence-however unstable, however ephemeral - through the connection the viewer makes between the image and the text and the resulting memory this realisation engenders. This strategy of commemoration is as oblique as the photographer's initial approach which seeks

11 See paulseawright.com.

12 Details of the circumstances of individual deaths for these and all the victims of the Troubles can be found in D. McKittrick, C. Thornton, S. Kellers, B. Feeney, Lost Lives: The Stories of the Men, Women and Children Who Died as a Result of the Northern Ireland Troubles, Edinburgh: Mainstream Publishing, 2004. 
to remember while avoiding even the slightest disturbance of whatever trace may continue to haunt these sites. The result is a series of glimpses into past trauma that succeed in generating an unobtrusive empathy for these forgotten victims.

We find another example of this caution and tact in the work of the Dublin-based photographer, David Farrell, whose now classic Innocent Landscapes focuses on the issue of the 'disappeared'. Farrell's contribution to the dialogue between photography and the political violence in the North is important not only in terms of the outstanding quality of his work, but also because of the nature of his - on-goingcommitment to this project.

Apart from Captain Robert Nairac, ${ }^{13}$ the disappeared were all members of the Catholic, nationalist community in the North whom the IRA and another Republican group, the INLA, had accused of collaboration with the British authorities. In all, some 17 men and women were kidnapped and 'disappeared' between 1972 and 1985. The fate of these people resurfaced in the context of the Peace Process when the Republican movement came under considerable pressure to provide information to the victims' families. The IRA negotiated with the British and Irish authorities, agreeing to conduct an internal inquiry and release information on the whereabouts of the bodies on condition that the perpetrators were not brought before the courts. The result was the Northern Ireland (Location of Victims' Remains) Act (1999) ${ }^{14}$ which set up a Commission designed to receive information as to where the bodies of victims had been buried and guaranteed immunity from criminal prosecution to those providing information to the Commission. On the basis of information received, it emerged that these people had been tortured and taken across the border before being buried in unmarked graves in bogs and forests or along beaches in the Republic of Ireland ${ }^{15}$. As Farrell explains:

The burial locations - Colgagh, Ballynultagh, Oristown, Templetown, Wilkinstown, Bragan and Faughart - contained a simple but final bitter twist: they were all in the south of Ireland. This small group of people had been exiled in death, creating a poignant and, as time progressed, haunting Diaspora of the Disappeared. ${ }^{16}$

The fact that the IRA should have decided to take the people - or their bodiesover the border before burying them in 'the South' is of central importance. During the Troubles, although inevitably the violence spilled over sporadically into the territory of the Republic, it was nonetheless firmly concentrated in the North. By crossing the border, this "Diaspora of the Disappeared" had entered Farrell's everyday envi-

13 Captain Nairic, a British intelligence agent working undercover, was kidnapped and murdered by the IRA in 1977.

14 For the text of the Act, see: http://legislation.gov.uk/ukpga/1999/7/body [access: 9.11.2018].

15 See "The Disappeared of Northern Ireland": www.thedisappearedni.co.uk [access: 9.11.2018]. So far, thirteen bodies have been found.

16 D. Farrell, "Text", available at: http://davidfarrell.org/landscape-as-witness/the-disappeared/innocent-landscapes-1999-2000/text/ [access: 9.11.2018]. 
ronment, thus demanding a response. Like Seawright, the violence in the North had suddenly become part of his own "lived experience", sharply reducing the distance that many in the Republic had sought to maintain with regard to what was happening there.

On the basis of the information received a number of sites along the border and in Meath and Wicklow were searched by the Irish authorities. When he visits the first site at Colgagh, immediately after the discovery of the remains of two of the victims, Farrell is immediately struck by the fact that "there was 'nothing' to photographcertainly nothing in a conventional documentary mode". What he was faced with was a landscape of "Arcadian beauty" that had been "violated" by the excavations that had been trying to follow the often scant or inaccurate information that was supposed to lead to the remains. It is this "scarification" of the landscape that becomes the driving force behind the work, as he sees it as "a powerful metaphor for the violence that had taken place there over twenty years ago that only now had become visible..."17

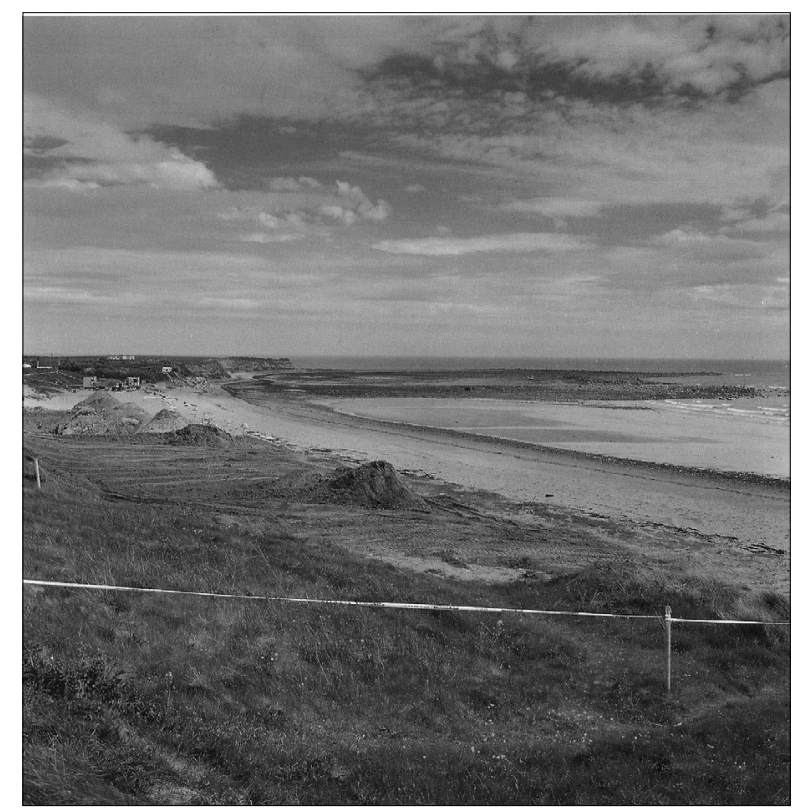

David Farrell, "Cooley Point, Jean McConville”, Innocent Landscapes. Reproduced by permission of the artist.

17 D. Farrell, Innocent Landscapes, Stockport: Dewi Lewis Publishing, 2001; D. Farrell, Revisits, Discovery and a Renewed Search (1999-2009), available at: http://source.ie/blog/?p=1659 [access: 9.11.2018]. 
Farrell photographs the traces of violence that are left in the landscape: whether that is the images of the diggers deployed to search for the bodies or the improvised altars and shrines members of the victims' families set up in the places where they thought the body may be buried. The approach to the violence itself is therefore invariably oblique, indirect. The series catalogues excavation work at a total of 7 sites. Needless to say, the result is particularly poignant with regard to the searches that failed to lead to the discovery of a body. In Farrell's work, the viewer's gaze cannot help but scan the landscape for the - absent - body of the victim that may or may not be hidden somewhere in the images he presents. The prolonged inability to locate the victim renders the entire landscape suspect. Unlike the Seawright series where each photograph focuses on an attested crime scene, everything in Farrell's beautiful, tranquil images is conceivably a murder site.

As with Seawright, time is an essential element of the photographic strategy. Farrell's work is indeed remarkable in terms of his long-term and on-going commitment to the project. He began working on Innocent Landscapes in 1999, soon after the signing of the Belfast Agreement, and has returned to the sites regularly ever since. These visits were in no way dependent on the tortuous unfolding of the excavations which were halted and re-started according to the drip feed of information coming from Republican sources. Thus, in an on-line text on Landscapestories, ${ }^{18}$ he explains that while he was working on the Innocent Landscapes project at Coghalstown Wood in Meath in 2000 he noticed how, already in the immediate aftermath of the excavation, "nature had begun to reclaim the wider landscape that had been upturned and searched". His initial impression of the "scarification" of the landscape was, therefore, qualified by the realisation that the landscape repairs itself and "absorbs" whatever violence is done to it. He therefore decided to return to the sites every year to "follow this process of re-absorption in subsequent years."

Positions and positioning are essential aspects in the overall narrative of the disappeared. The photographs in the Innocent Landscapes series are interspersed with detailed maps of the areas where the Republican movement had indicated that they had dumped the bodies, with certain areas circled in pen to indicate roughly where the operative thought the body might be. Although some information proved relatively accurate, this was not always the case. These lapses in memory are an essential element of Farrell's project in that they highlight the complexities surrounding the memory of these particular dead. Although the Republican movement had attempted to impose a collective amnesia around these crimes, the families of the victims had continued to refuse to forget. However, even though political circumstances forced a change of tack, the fact that the murders had taken place so long ago meant that the memory of the operative who carried out the murder - if he was still alive-was often vague as to the exact location of the burial site. Farrell clearly sees these issues

18 David Farrell, “The swallowing tree”, available at: http://www.landscapestories.net/issue-07/021-david-farrell?lang=en [access: 9.11.2018]. 


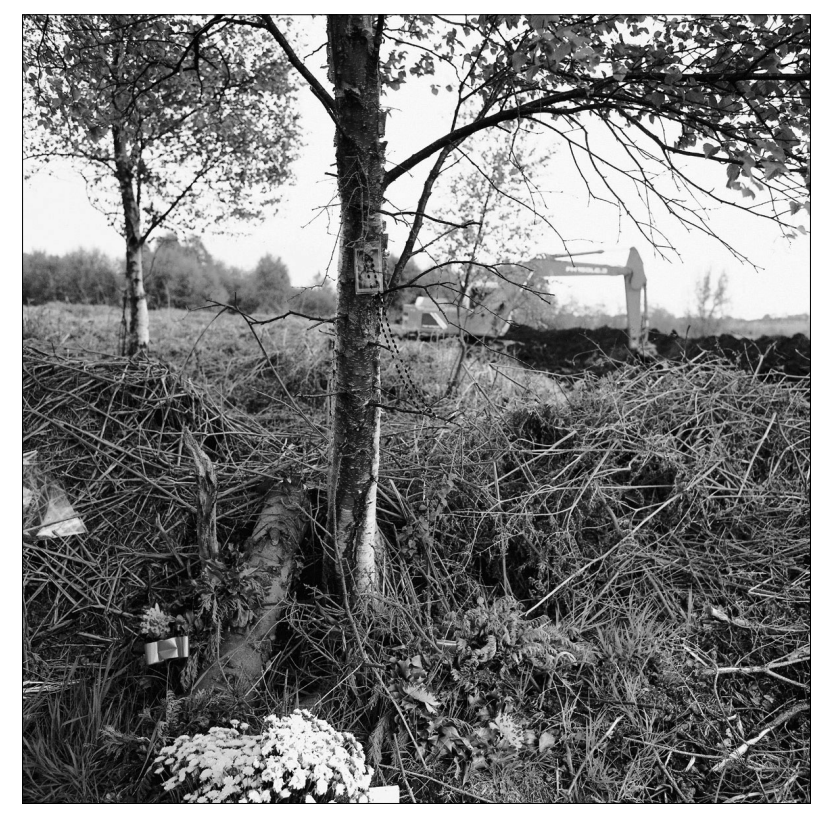

David Farrell, "Wilkinstown", 2000, Innocent Landscapes. Reproduced by permission of the artist.

of memory as central to the narrative in that in the context of his own work he makes no effort to frame his own memory in relation to the sites he re-visits from one year to the next. Thus, in his record of nature's "re-absorption" of the sites, he makes no particular attempt to ensure that he will photograph a given site from 'exactly' the same position every year. Rather than using co-ordinates on a map, or leaving a marker on site, for example, he allows his own memory to guide him back from year to year - even though he realises that he will not always recognise the exact spot because of the growth of the vegetation over the intervening period. Thus, recalling the lapses in memory surrounding the location of the dead, he allows the project to develop under the influence of what he calls his own "fallibility of recall". Similarly, even when he manages to locate the site he had photographed the previous year, the changes effected by the vegetation may make it materially impossible for him to position his camera in exactly the same spot. As with the vagaries of his memory, Farrell thus allows the landscape to re-position his camera in accordance with its own logic, in recognition of the fact that the landscape itself had become a recognisable actor in the telling of this narrative.

He goes on to explain how when he returns to the wood in 2006 he re-discovers a religious picture and a set of rosary beads that had been pinned to a tree by a relative as a gesture of hope that the body might soon be found. Over the years the tree had begun to "swallow" the image and the beads. This image of "ingestion", of what 
he calls the "swallowing tree", becomes a powerful metaphor for the way in which the landscape absorbs the bodies of the disappeared but also how it - literally-incorporates their memory into a living thing: "A memory being slowly subsumed by voracious nature and the passage of time." It is this capacity to absorb, to efface the horror of the past and to transform that memory into the outstanding beauty of these natural sites that offers the hope of some closure to this narrative.

\section{Intrusive memory}

In sharp contrast to this allusive, lateral approach, showing images of violence in Northern Ireland has a long, chequered history. Thus, from the late 1960s on, the public got used to seeing images of the aftermath of political violence in the newspapers and on regional television. Alongside this day-to-day feed of often explicit images of violence, the police and even the political parties did not hesitate to use images of victims of violence for propaganda purposes. Thus, the future First Minister of Northern Ireland, Peter Robinson, was the author of a DUP pamphlet, Savagery and Suffering: A Glimpse at the Savagery and Butchery of the IR $A^{19}$, designed specifically to 'show' the results of republican violence. In this context, Robinson includes a photograph of the charred remains of a body barely distinguishable among the ashes on the floor of a burnt-out train that had been bombed by the IRA. He places this image underneath another photo of the IRA 'guard of honour' at the funeral of one of the attackers who had died during the operation, bearing the caption: "For what do the IRA 'honour' him?"

This type of frontal approach to the results of violence, which raises fundamental moral questions with regard to what Sontag sees as the exploitation of "the pain of others" ${ }^{20}$, reminds us of the vast archive of photographic material relating to the Troubles that is locked away in the forensic files of the police and the other security services. Some of this material has emerged over recent years, for example, in the Royal Ulster Constabulary Scene of the Crime archive. Siún Hanhrahan, ${ }^{21}$ who was given access to this "massive" archive of material, discusses the ethics of "looking at' these photographs which present the full range of violence in Northern Ireland in detail that is at once "meticulous" and "horrific". She is struck by the "matter-of-fact coldness" of the material which she explains by the fact that the photographs are "not taken to prompt empathy" but rather "as part of a process of redress". These images were designed to respect the highest levels of "neutrality" and "objectivity" because they were to form part of a carefully composed judicial narrative. Importantly, in

19 P. Robinson, Savagery and Suffering: A Glimpse at the Savagery and Butchery of the IRA, DUP, 1980.

20 S. Sontag, Regarding the Pain of Others, London: Hamish Hamilton, 2003.

21 S. Hanrahan, "Bearing witness: A discussion of the Royal Ulster Constabulary's Scene of the Crime Photographic Archive", Source, Issue 18, Spring 1999, available at: http://www.source.ie/issues/ issues0120/issue18/is18artbeawit.html [access: 9.11.2018]. 
relation to the central issue of 'showing' the results of violence on the victim, she notes for example how in the books of photographic evidence concerning murder, the body is shown only "to record its situation". This is a central issue in that, throughout the text, she is clearly preoccupied with the "anxiety" generated by looking at these images since she knows she does not belong to the highly restricted group of those initially intended to see: the photographer, the officers leading the investigation, the judges and the members of the jury. Entering the hitherto intensely controlled intimacy of the crime scene and the equally controlled judicial process poses a real ethical dilemma. And yet, she ends by underlining how her work on the archive led her to ask if society as a whole did not need to "confront" the reality of the violence that it had allowed to develop in its midst rather than allowing it to be channelled off into what was effectively the sealed container of a closed archive. She argues that such confrontation could only enhance the material's function as an instrument of (collective) "redress".

An interest in the frontal representation of violence has emerged in the work of a handful of Northern Ireland individual artists, and perhaps most notably in the photography of Malcolm Craig Gilbert. Gilbert's work came to notice through his Post Traumatic Exorcism Series, when a selection of images from the series appeared in the Belfast photography magazine, Source, in its Autumn 2010 issue, and for which he won a Photoicon prize.

On his site, Gilbert explains that he had been a police officer for eighteen years during the Troubles, but was "medically retired due to the effects of Post Traumatic Stress Disorder." 22 He goes on to say that the images in the series are: "[c]leaved from a pastiche of personal memories, fears, anxieties, paranoia, and the things I never talked about; this work now shows, and brings to life, my true feelings and emotions of those times without censor." These 'intrusive memories' become the catalysts for a number of highly staged images which at times contain graphic - if highly codified-scenes of violence. The images 'show' not only the results of violence, but also, more disturbingly perhaps, the process of violence as it unfolds.

In a short interview for the Gallery of Photography Ireland he explains that his work is never "contextualised" but that he leaves it "up to the viewer to contemplate the realms of the before and the after" ${ }^{\prime 2}$. In the same interview, comparing digital to

22 According to a report published under the auspices of the WHO by the Bamford Centre for Mental Health and Wellbeing (University of Ulster) and the Northern Ireland Centre for Trauma and Transformation in December 2011, entitled The Economic Impact of Post Traumatic Stress Disorder in Northern Ireland, almost $40 \%$ of people in Northern Ireland suffer PTSD as a result of a conflict related traumatic incident. The research found that, "Northern Ireland has the highest level of 12-month and lifetime PTSD among all comparable studies undertaken across the world including other areas of conflict." See: https://www.ulster.ac.uk/news/2011/december/ni-has-worlds-highest-rate-of-posttraumatic-stress-disorder [access: 9.11.2018].

23 This interview, entitled Thinking photography with Malcolm Craig Gilbert, is available on Vimeo at: https://vimeo.com/134046491 [access: 9.11.2018]. 
film photography, he says that what attracts him to the latter is that it "encourages [him] to try and produce the whole story in the confines of a single frame." Narrative is, therefore, at the centre of his strategy. The image is constructed and presented as if it were a still in a moving film. However, by refusing to shoot the film, by concentrating on the production of a single shot, he transfers the construction of the scenario into the imagination of each of his viewers and thus into the community at large.

Unlike Tarantino, one of Gilbert's main influences, the 'flashes' of (sometimes) hyper-violence that Gilbert constructs are all the more plausible in that they are anchored in a recognisable reality that will be shared by many of his viewers. Indeed, what people see and how people see what they see depends on their ability to decode what is shown; while many outside Northern Ireland will see only staged, psychopathic, urban-based violence whose political subtext will be either largely absent or totally opaque, those who are familiar with the visual codes of the society Gilbert foregrounds will identify clues that will allow them to construct possible scenarios, identify the murderers and perhaps their victims. Gilbert clearly sees the construction of these multiple narratives as an essential part of the political—and social—function of his work.

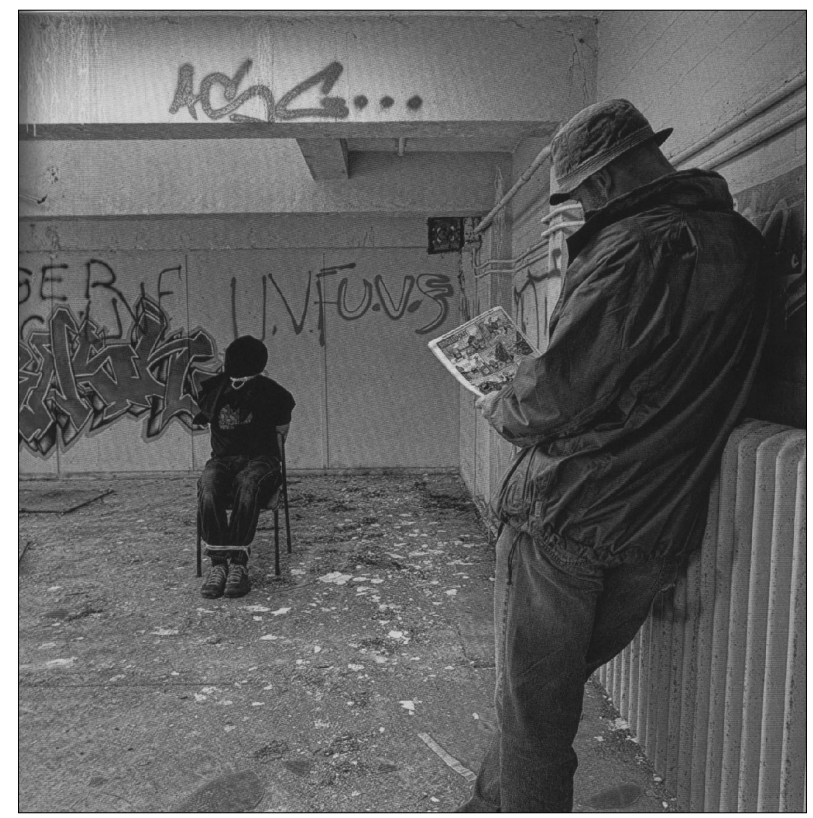

Malcolm Craig Gilbert, "Singled out”, Post Traumatic Stress Exorcism series. Reproduced by permission of the artist.

Thus, in "Singled out", the graffiti on the walls will act as a form of signature. It is clear that the viewer is meant to identify the dominant logo- the acronym UVF repeated three times on the back wall in three different scripts, by three different 
hands, with varying levels of legibility. These three icons 'frame' the seated figure that is at the focus of the image. Since graffiti indicates territorial ownership, we are to understand that we are in Loyalist territory and that this is therefore a story of Loyalist crime.

We find further territorial markers in "The infidel" which is also constructed within a similarly coded geographic logic. Here, the naked victim at the centre of this visual narrative has been taken to a piece of waste land dominated by the 'Goliath' crane, a key icon of the Harland and Wolff shipyard. The theatrical structuring of the image plays with popular representations of the Old Testament sacrifice of Isaac, re-located on the edges of East Belfast. All of the elements are present - the mountain, reinvented in the form of the crane looming over the scene, the young sacrificial male victim, the knife about to slice his throat. However, even though, like Abraham, the murderer is momentarily distracted by the plane on its way to or from Belfast airport, we are to conclude that this is a sacrifice that will probably not be interrupted.

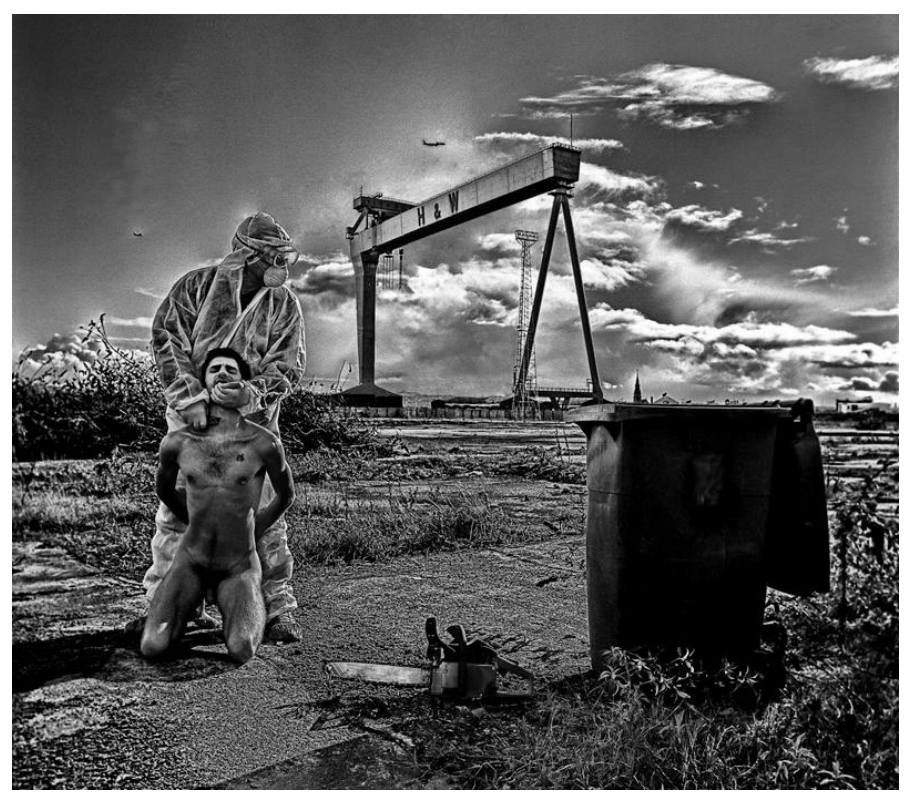

Malcolm Craig Gilbert, “The Infidel”, Post Traumatic Stress Exorcism series. Reproduced by permission of the artist.

However, across the series as a whole, this type of political association is an exception as it is often impossible to identify information of this sort. In the majority of cases the violence takes place in nondescript suburban interiors or against the ruins of a derelict industrial landscape. Indeed, the almost exclusively urban settings and 


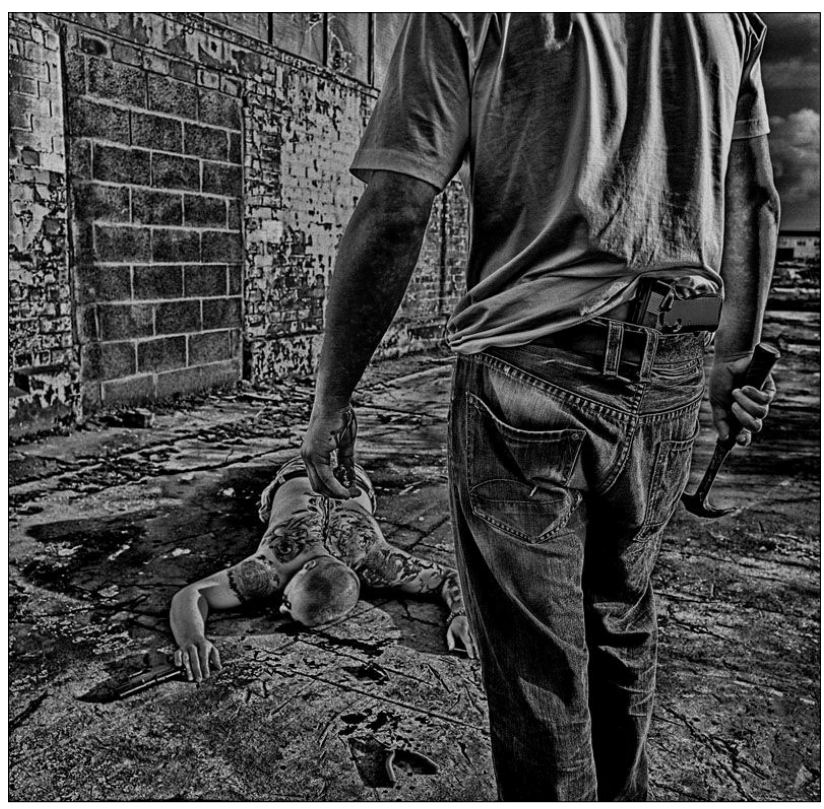

Malcolm Craig Gilbert, "An Eye for an Eye”, Post Traumatic Stress Exorcism series. Reproduced by permission of the artist.

the modus operandi of the violence he represents are framed in terms of what Pierre Musso would call an "industrial imaginary"24_in this case rather a post-industrial imaginary. Thus, some of the most striking scenes of torture and murder that Gilbert creates are set in the shells of the abandoned factories and in the derelict sites that formed an integral part of the Belfast landscape before the gradual reconstructionand gentrification — of the city under the influence of the Peace Process.

What has been salvaged from the past is clearly the individual skill of the menthis is an almost exclusively masculine world - who had worked in these now deserted sites. Insofar as Gilbert's characters constantly show their interest in technique, they emerge very much as skilled workman. This comes through strongly in the tools which are omnipresent in the images. However, the tools - the chainsaw, the hammer, the pliers - are deviated from their everyday use and used as instruments of torture against the human body. In this post-industrial environment, one that has seen the collapse of the textile industries and the inexorable contraction of the shipbuilding industry that had formed the basis of the prosperity of the North, the evidence of the images would appear to suggest that the body of the victim is the only raw material

24 See P. Musso, L'imaginaire industriel, Paris: Éditions Manucius, 2013, part of the "modélisation des imaginaires" series. 
left for society to work on. They become the instruments of a hyper-violent, urban Passion - the hammer and pliers that feature prominently in many of these images are emblems of the exemplary suffering of Christ - re-enacted along the periphery of this decaying city space.

Issues of technical skill come through also in the attention to form that constitutes such an essential element of Gilbert's aesthetic. Thus great attention is paid to the positioning of the body in this derelict industrial space. The basic preoccupation is with symmetry. The images are frequently structured around the figure of the victim, carefully positioned within the functional geometry of the surrounding space. This is another aspect of the professionalism of the killers, their attention to detail, the workmanship with which these actions are prepared and carried out. After all, these are the people who had spent their working lives respecting the requirements of draftsmen and engineers in the hundreds of factories and workshops across the city. Above all, the resulting visual balance demonstrates how, at some perverse level, violence can re-establish a form of (ephemeral) order within a space-and by extension a society-in decomposition.

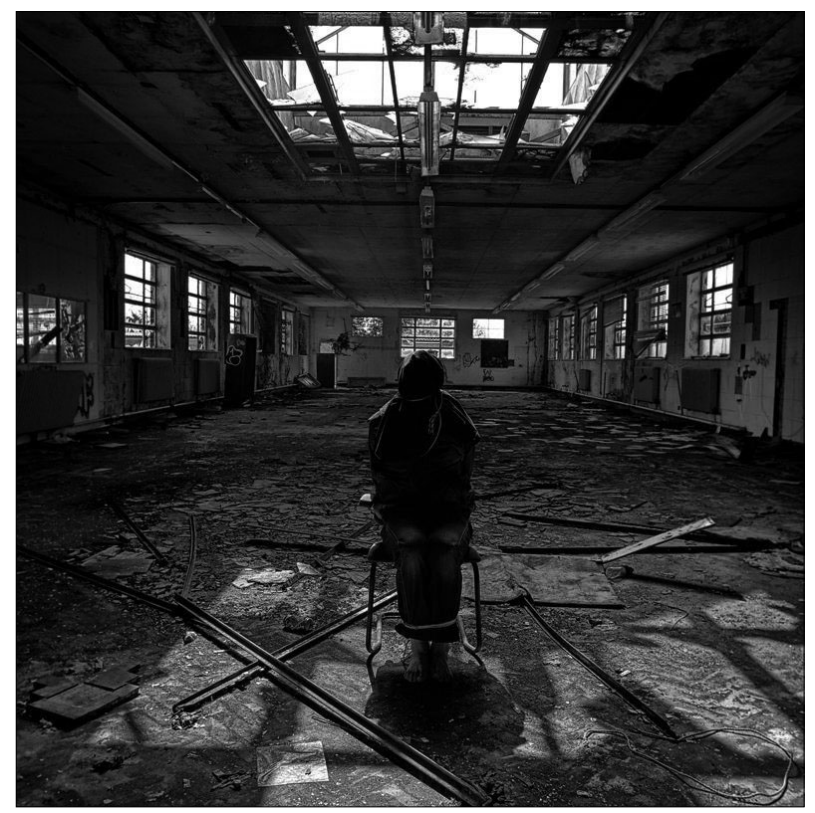

Malcolm Craig Gilbert, “Abandonment”, Post Traumatic Stress Exorcism series. Reproduced by permission of the artist.

Gilbert's attention to generating visual order is closely linked in to the way he uses sight. Issues of seeing and not seeing are central to several of the images in the 
series. ${ }^{25}$ Whereas the perspective of the onlooker allows him to appreciate the order built into the image, the victim, of course, is unaware of that structure, and the impression of order of which he is such a central element. In Gilbert's world, sightlessness is an attribute of the victim, the hostage, the condemned man. Sight is linked in to mechanisms of control. Sight is often reserved for the torturer, the murderer - and, of course, for us, his accomplices, the people looking at the image. Thus, in an image like "Abandonment", for example, the lone figure finds himself in the centre of a perfectly composed image that again evokes a crucifixion scene. Bathed in light streaming through the broken windows, he sits immobilised beside an empty cross formed from two metal beams lying on the floor. However, whereas in representations of the crucifixion the figure of Christ is invariably the centre of a host of other figures, here in this post-industrial Golgotha, he is quite alone. ${ }^{26}$ Indeed the title of this image encourages us to hear "My God, my God, why did you abandon me?"27

It is interesting that nothing in the images betrays the identity of the victims or the reasons for their being held, tortured or murdered. This is most evident in the images where the victims are actually hooded, ensuring facelessness and anonymity. Whereas at times he gives us clues as to the identity of the kidnappers, it is almost as if Gilbert has gone out of his way to blur our ability to identify who is tied up in the chair. Just as in Seawright's refusal to identify the religion of the victims of the tit-for-tat violence of the 70 s and 80 s, so Gilbert shows an unidentified and ultimately unidentifiable victim at the centre of the image. Thus, the victim in these photographs can be seen as "standing for" anyone from the community at large. To quote the title of the appalling 1995 film by Thaddeus O'Sullivan, Nothing Personal, the violence here is not (necessarily) personal — rather, it is violence directed at the body of society as a whole.

But at the same time, it could be argued that in submitting these images before us, he places the victim on the other side of the lens, outside the frame looking in. At some level, the Northern Ireland community is being invited to see itself held captive, immobilised, deprived of sight —or is it vision? —-by the violence that it has allowed to develop in its midst and that became such an integral part of everyday reality.

25 See for example "Covert operations" or "Rewind/Replay" in the Post Traumatic Stress Exorcism series.

26 See other, infinitely more explicit, representations of the crucifixion in "Tout" and "The patsy", the latter showing an RUC police officer with hands and feet nailed into the furniture and floor of an abandoned room.

27 Mathew 27: 46, Good News Translation. 


\section{Conclusion}

Malcolm Craig Gilbert's work began as a vehicle for coming to terms with the effects of personal trauma, but inevitably, in the very act of "exhibition", it takes on a community dimension. By constructing and showing these flashes of his "intrusive memories' he allows us to see what is normally not seen, what is usually hidden from view, i.e. the processes of violence and the opportunities for crime they open up. ${ }^{28}$

Gilbert's work is about concretising and confronting these images of trauma. His 'exorcism' of the past is infinitely more self-conscious, and above all more brutal than that of Seawright or Farrell. But although their work takes a more indirect approach, it too seeks to lay the ghosts of the past to rest. All three attempt to stop the viewer in their tracks in order to 're-consider' the violence of the past. The idea that Northern Ireland could simply move on after thirty years of violence has proved overly optimistic. Generating and confronting images within the community, whether that is done through the hyper-real violence of Gilbert's carefully structured mises en scène, or whether it is done through more subtle invitations to empathy, the work of these photographers indicates something of the difficulties the Northern Ireland community is facing in trying to come to terms with the violence of its past.

\section{References}

Baker, S., "The unspeakable”, Source, Autumn 2010, Issue 64, 31. [This essay introduced a selection of Malcolm Craig Gilbert's work entitled: "Malcolm Craig Gilbert, Post traumatic exorcism", Source, Autumn 2010, Issue 64, 31-39.]

Carville, J., Paysages innocents, London: Reaction Books, 2011.

Farrell, D., Innocent Landscapes, Arles: Actes Sud, 2001.

Farrell, D., The Swallowing Tree, Latent Images Editions, 2014.

Farrell, D., "The Swallowing Tree", alandscapestories.net.

Graham, C., Northern Ireland: 30 Years of Photography, Belfast: Belfast Exposed/MAC, 2013.

Hewitt, J., Art in Ulster 1: 1557-1957, Belfast: Blackstaff Press, 1977.

Hutchinson, W. (ed.), "Imagining Ireland's Dead / La mort en Irlande: Le corps imaginé", Interfaces: Image, Texte, Langage 2004, $\mathrm{N}^{\circ} 23$.

Kelly, L., Thinking Long: Contemporary Art in the North of Ireland, Kinsale: Gandon Editions, 1996.

L'imaginaire irlandais, Paris: Hazan, 1996.

Lardinois B., Williams, V., Magnum Ireland, London: Thames \& Hudson, 2005. (With an introduction by John Banville).

Limpkin, C., The Battle of the Bogside, Harmondsworth: Penguin Books, 1972.

Loftus, B., Mirrors: William III and Mother Ireland, Dundrum: Picture Press, 1990.

${ }_{28}$ Several of the images in the series, for example "A little something for the pain" or "A friendly game of cards", play with stereotyped images of the drugs dealer. 
Loftus, B., Mirrors: Orange and Green, Dundrum: Picture Press, 1994.

Long, D., Visual Art and the Conflict in Northern Ireland, Belfast: Arts Council of Northern Ireland, n.d.

McAvera, B., Marking the North: The Work of Victor Sloan, Dublin \& New York: Open Air; Impression Gallery, 1990.

McGonagle, D., O’Toole, F., Levin, K., Irish Art Now: From the Poetic to the Political, London \& New York: Merrell Holberton; Independent Curators International, 1999.

McKittrick, D., Thornton, Ch., Kellers, S., Feeney, B., Lost Lives: The Stories of the Men, Women and Children Who Died as a Result of the Northern Ireland Troubles, Edinburgh: Mainstream Publishing, 2004.

Murphy, Y., Leonard, A., Gillespie, G., Brown, Ch. (eds.), Troubled Images: Posters and Images from the Northern Ireland Conflict from the Linen Hall Library, Belfast: The Linen Hall Library, 2001.

Musso, P., L'imaginaire industriel, Paris: Éditions Manucius, 2013.

Seawright, P., "Sectarian Murder" series, available at: paulseawright.com.

Sloan, V., Selected Works, 1980-2000, Belfast: Ormeau Baths Gallery / Orchard Gallery, 2001. Sontag, S., Regarding the Pain of Others, London: Hamish Hamilton, 2003.

www.thedisappearedni.co.uk 